\title{
Treating refractory obsessive-compulsive disorder: what to do when conventional treatment fails?
}

\author{
Tratando o transtorno obsessivo-compulsivo refratário: \\ o que fazer quando tratamentos convencionais falham?
}

\author{
Adelar Pedro Franz, ${ }^{1}$ Mariana Paim,${ }^{1}$ Rafael Moreno de Araújo, ${ }^{1}$ Virgínia de Oliveira Rosa, ${ }^{1}$ \\ Ísis Mendes Barbosa, ${ }^{2}$ Carolina Blaya, ${ }^{3}$ Ygor Arzeno Ferrão ${ }^{3}$
}

\begin{abstract}
Obsessive-compulsive disorder (OCD) is a chronic and impairing condition. A very small percentage of patients become asymptomatic after treatment. The purpose of this paper was to review the alternative therapies available for $O C D$ when conventional treatment fails. Data were extracted from controlled clinical studies (evidence-based medicine) published on the MEDLINE and Science Citation Index/Web of Science databases between 1975 and 2012. Findings are discussed and suggest that clinicians dealing with refractory $O C D$ patients should: 1 ) review intrinsic phenomenological aspects of $O C D$, which could lead to different interpretations and treatment choices; 2 ) review extrinsic phenomenological aspects of OCD, especially family accommodation, which may be a risk factor for non-response; 3 ) consider non-conventional pharmacological approaches; 4) consider non-conventional psychotherapeutic approaches; and 5) consider neurobiological approaches.

Keywords: refractoriness, resistance, obsessive-compulsive disorder, treatment response, risk factors, prognosis.
\end{abstract}

\section{Resumo}

O transtorno obsessivo-compulsivo (TOC) é uma doença crônica e incapacitante. Uma pequena porcentagem de pacientes se torna assintomática após o tratamento. O objetivo deste trabalho foi revisar as alternativas terapêuticas para o tratamento de TOC quando os tratamentos convencionais falham. Os dados foram extraídos de estudos clínicos controlados (medicina baseada em evidências) publicados nas bases de dados MEDLINE e Science Citation Index/Web of Science entre 1975 e de 2012. Os resultados são discutidos e sugerem as seguintes abordagens para profissionais que lidam com TOC refratário: 1) rever aspectos fenomenológicos intrínsecos ao TOC, o que pode levar a entendimentos diferenciados e à escolhas terapêuticas distintas; 2) rever aspectos fenomenológicos extrínsecos ao TOC, principalmente acomodação familiar, que pode ser fator de risco $p$ ara a não resposta; 3) considerar abordagens farmacológicas não convencionais; 4) considerar abordagens psicoterapêuticas não convencionais; e 5) considerar abordagens neurobiológicas.

Descritores: refratariedade, resistência, transtorno obsessivo-compulsivo, resposta ao tratamento, fatores de risco, prognóstico.

\footnotetext{
${ }^{1}$ Psychiatric resident, Universidade Federal de Ciências da Saúde de Porto Alegre (UFCSPA), Porto Alegre, RS, Brazil. ${ }^{2}$ Medical student, UFCSPA. ${ }^{3}$ Associate Professor of Psychiatry, UFCSPA.

Financial support: none.

Submitted Aug 27 2012, accepted for publication Nov 14 2012. No conflicts of interest declared concerning the publication of this article.

Suggested citation: Franz AP, Paim M, Araújo RM, Rosa VO, Barbosa IM, Blaya C, et al. Treating refractory obsessive-compulsive disorder: what to do when conventional treatment fails? Trends Psychiatry Psychother. 2013;35(1):24-35.
} 


\section{Introduction}

Obsessive-compulsive disorder (OCD) is a chronic and impairing condition ${ }^{1}$ with prevalence rates ranging from 0.3 to $3.1 \% .^{1,2}$ Despite the availability of several treatment approaches for OCD, full remission is quite rare. ${ }^{3,4}$ Previous studies have shown that almost $60 \%$ of the patients treated with selective serotonin reuptake inhibitors (SSRIs) experience a $25-35 \%$ decrease in symptoms according to the Yale-Brown Obsessive Compulsive Scale (Y-BOCS), which is not enough to reach quality of life. ${ }^{5-7}$ Non-response is defined as a reduction of $<25 \%$ in $\mathrm{Y}$-BOCS scores, ${ }^{8}$ whereas response is characterized as a $35-50 \%$ score reduction. ${ }^{9}$ Despite the modest percentage reduction in Y-BOCS scores considered to be indicative of treatment response, it is far higher than the response traditionally obtained with placebo (3 to $5 \%$ ). ${ }^{10}$

OCD remission has been defined in the literature as improvement observed after an intervention, characterized by the absence of symptoms or a Y-BOCS score $\leq 16 .{ }^{11}$ Pallanti et al. ${ }^{12}$ have proposed the term recovery to indicate an almost complete disappearance of symptoms, corresponding to a Y-BOCS value of $\leq 8$. Table 1 lists the different treatment response categories usually considered in OCD.

Table 1 - Treatment response categories in OCD (based on Pallanti et al. ${ }^{11}$ )

I) Recovery: Not at all ill; score $\leq 8$ on $Y$-BOCS

II) Remission: Score $\leq 16$ on $\mathrm{Y}$-BOCS

III) Full response: $\geq 35 \%$ reduction in $Y$-BOCS

IV) Partial response: $25-35 \%$ reduction in Y-BOCS

V) Non-response (resistant): $<25 \%$ reduction in Y-BOCS

VI) Relapse: Symptoms return (25\% increase in Y-BOCS) after 3 months of "adequate" treatment/remission

VII) Refractory: No change (improvement or worsening) with any conventional therapy

$\overline{\mathrm{OCD}}=$ obsessive-compulsive disorder; Y-BOCS = Yale-Brown Obsessive Compulsive Scale.

Table 2 - Conventional treatment options available for OCD (based on Bandelow et al. ${ }^{6}$ )

\begin{tabular}{l}
\hline Pharmacological treatment \\
First line: \\
Escitalopram, $10-20 \mathrm{mg} /$ day \\
Paroxetine, $40-60 \mathrm{mg} /$ day \\
Sertraline, $50-200 \mathrm{mg} /$ day \\
Fluvoxamine, $100-300 \mathrm{mg} /$ day \\
Fluoxetine, $40-60 \mathrm{mg} / \mathrm{day}$ \\
Clomipramine, $75-300 \mathrm{mg} /$ day \\
Second line: \\
Citalopram, $20-60 \mathrm{mg} /$ day \\
Mirtazapine, $30-60 \mathrm{mg} /$ day \\
Psychotherapy \\
Cognitive-behavioral therapy (exposure and response \\
prevention) \\
OCD = obsessive-compulsive disorder.
\end{tabular}

"Resistant patients" were defined by Rauch \& Jenike ${ }^{13}$ as patients who participated in trials assessing first-line therapies but did not show a satisfactory response; "refractory patients" were defined as patients who did not respond appropriately to several adequately administered conventional treatments. However, the authors do not specify how many treatments should be tested before a patient can be classified as refractory. Conventional treatment options are listed in Table 2.

The purpose of this paper was to review the therapeutic alternatives available for the treatment of OCD when conventional treatment fails. Data are discussed and organized into five subheadings.

\section{Methods}

The present paper draws on evidence from controlled clinical studies, thus adhering to the principles of evidence-based medicine. Data were collected from articles published on the MEDLINE and Science Citation Index/Web of Science databases between 1975 and June 2012. A few additional trials were retrieved by hand-searching. Open studies and case reports were also reviewed with a focus on treatment suggestions for patients not responding to conventional treatments. However, the results of these articles have to be interpreted with caution, because of their strong placebo effect and possible publication bias.

\section{Results}

\section{Intrinsic phenomenological aspects of $O C D$ as risk factors for refractoriness}

Table 3 lists intrinsic risk factors related to the phenomenology of OCD that may influence response to conventional treatment. Most of such risk factors are described in more detail below.

Table 3 - Intrinsic phenomenological risk factors for poor response to conventional treatment of OCD

Early onset
Content of obsessive-compulsive symptoms
Hoarding
Sexual
Religious
$\quad$ Somatic
Overvalued ideas and poor insight
Sensorial phenomena
Higher symptom severity at onset
Presence of tics
Comorbidities
$\quad$ Schizotypal, borderline and paranoid personality disorders
Anankastic personality disorder




\section{Early onset}

According to some studies, ${ }^{14,15}$ patients with early onset OCD have a poor prognosis, with a chronic course and little response to treatment with clomipramine. ${ }^{14}$ In a community treatment group, more severe initial symptoms were associated with greater improvement during treatment. ${ }^{16}$ Otherwise, studies have failed to find relationships between early onset and treatment response. ${ }^{17}$

\section{Hoarding}

Hoarders were significantly more likely than nonhoarding patients to have severe OCD symptoms, poor insight, a high prevalence of comorbid schizotypal or obsessive-compulsive personality disorders, a close association with the symmetry dimension, and a poor treatment outcome. ${ }^{18}$

\section{Overvalued ideas and poor insight}

Overvalued ideas appear to have an important role in OCD treatment outcome. Although some reports have indicated that patients with overvalued ideas improve following intensive treatment, ${ }^{19,20}$ other reports suggest that treatment often fails or is not very effective, ${ }^{20,21}$ or yet that exposure and response prevention is not as effective as drug treatment ${ }^{19,22}$ in these patients. In the study by Neziroglu et al., ${ }^{23}$ the presence of high-intensity overvalued ideas was related to a worse response to pharmacological treatment combined with behavioral psychotherapy.

Patients with impaired or poor insight also tend to respond less effectively to pharmacological and behavioral treatment. ${ }^{24,25}$ Eisen et al., ${ }^{26}$ however, found no correlation between the degree of insight and response to sertraline in a multicenter study.

\section{Comorbidities}

Several studies have suggested that personality disorders are associated with greater symptom severity and poorer outcomes in OCD. ${ }^{27-29} \mathrm{~A}$ cross-sectional study aimed to compare possible differences in personality traits between responder and non-responder OCD patients found positive associations, especially for low self-directedness, with poor treatment response in obsessive-compulsive patients ${ }^{27}$ : patients with low self-directedness were more susceptible to engaging in responses aimed at allaying the anxiety (compulsions) rather than responses with delayed but healthier consequences (preventing compulsions). ${ }^{27}$

\section{Tics}

The only predictive factor of poor therapeutic response so far confirmed in OCD is the presence of comorbid tic disorders. ${ }^{30}$ The early onset of tics has also been associated with a worse prognosis. ${ }^{31}$

\section{Sex}

Therapeutic response has not been associated with sex in several studies on predictors of pharmacological treatment response in OCD patients. ${ }^{32-35}$

\section{Extrinsic phenomenological aspects of OCD as risk factors for refractoriness}

Table 4 lists some external factors that may interfere with adequate treatment outcomes in OCD patients. ${ }^{36}$ Figure 1 illustrates how these factors relate to one another.

Table 4 - Extrinsic phenomenological risk factors for poor response to conventional treatment of OCD

Constitutional/individual physiological features

Family support and functioning ${ }^{36}$

Compliance with available treatments (psychiatric drugs, psychotherapies)

High costs associated with OCD treatment (psychiatric drugs, psychotherapies)

Other psychosocial barriers

$\mathrm{OCD}=$ obsessive-compulsive disorder.

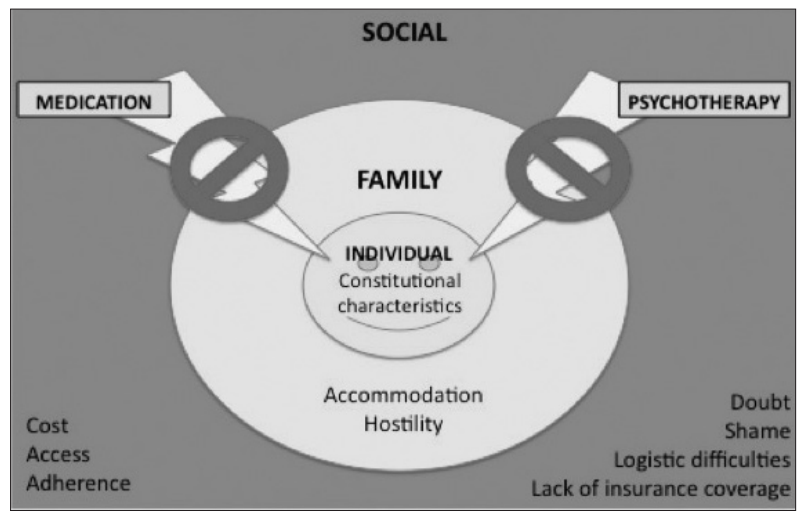

Figure 1 - External factors that may interfere with adequate treatment

\section{Constitutional/individual physiological features}

Individual characteristics such as genetic factors, age, weight, body composition, and nutritional status can modify the effects of drugs on the patient's system. Similarly, external aspects inherent to the drugs can also significantly change the intended effects, e.g., physical and chemical characteristics, pharmaceutical formulation and conditions of use (dose, acute or chronic administration and interaction with other drugs). It is particularly important to consider the induction or inhibition of hepatic enzymes resulting from drug interactions.

\section{Family support and functioning}

Family accommodation

Family accommodation is the process whereby family members of patients with OCD assist or participate in 
the patients' rituals; it can be measured using the Family Accommodation Scale (FAS). ${ }^{37,38}$ Calvocoresi et al. reported $61 \%$ of mild or no accommodation in families of patients with OCD. ${ }^{37}$ Stekette et al. reported that a high family accommodation index was associated with worse therapeutic results after behavioral therapy, ${ }^{39}$ pointing to a direct relationship between symptom reinforcement and deterioration of family relations. It is therefore reasonable to expect higher family accommodation scores in families with more severe, resistant or refractory patients.

Ferrão etal. observed low family accommodation scores in the families of patients who responded to treatment vs. high scores in those of refractory patients. ${ }^{17}$ Albert et al. showed that family accommodation was common, occurring on a daily basis in most family members, with provision of reassurance $(47 \%)$, participation in rituals (35\%) and assisting with avoidance strategies (43\%) being the most frequent practices.

Family hostility

Similarly to family accommodation, previous studies have related high rates of perceived hostility with worse therapeutic response, especially in patients receiving behavioral therapy. Steketee et al. carried out a longitudinal study and analyzed the levels of hostility in a heterogeneous group of 75 adult patients with OCD and panic disorder with agoraphobia receiving behavioral therapy. ${ }^{40}$ After 16 weeks, perceived family hostility influenced the patients' responses to exposure treatment: those who lived in more hostile environments and who reported feelings of sadness because of perceived criticism showed higher levels of anxiety during the sessions. Other studies have also associated higher ratings of family hostility and criticism with poorer outcomes. ${ }^{41}$ In particular, Emmelkamp et al. demonstrated that paternal, but not maternal, rejection was associated with poorer outcome. ${ }^{42}$

In an inpatient group, Boschen et al. found that marital status was a significant predictor of treatment outcome, with better outcomes for those who were married or lived with a partner vs. those not in a relationship. This same association was not observed in the community treatment group. ${ }^{16}$

\section{Compliance with and cost of available treatments}

\section{Psychiatric drugs}

Usually, even initial doses of psychiatric medications can cause undesirable effects such as dry mouth, constipation, sexual disorders, sleep alterations, etc. Because the doses given to OCD patients are generally high, ${ }^{43}$ the probability and intensity of such effects increase. In patients who do not respond to standard doses, one possibility is to enhance treatment effects ${ }^{43}$ by combining other drugs; however, this strategy may maximize side effects and thus reduce patient compliance.

The high cost of some medications restricts access to treatment and motivates the patient to look for less expensive alternatives, which sometimes are not effective.

\section{Psychotherapy}

Similarly to psychiatric drugs, psychotherapies available for OCD (e.g., behavioral therapy) usually require a greater number of sessions and a longer treatment course. ${ }^{43}$ It is therefore possible to assume that $O C D$ treatment will often be more expensive when compared with other psychiatric disorders. Unfortunately, there are no studies on the average cost of OCD treatment in Brazil, considering either direct or indirect costs (drugs or psychotherapy vs. OCD-related loss and disability). However, OCD is among the top 10 conditions with the highest rates of morbidity, ${ }^{44}$ so it probably accounts for significant costs to the public health system, both due to the frequent and continuous use of health care facilities and the patients' impaired work capacity. In 1990, the Epidemiological Catchment Area (ECA) program estimated that OCD-related reduction or loss of productive capacity cost to the United States, during that year, approximately $\$ 5.9$ billion dollars, or $70.4 \%$ of the total cost of OCD to the government. ${ }^{2}$

If access to psychiatric drugs is already restricted because of their high cost and low availability at public health care services, access to psychotherapies provides grounds for even greater concerns. In the case of $O C D$, techniques with proven efficacy ${ }^{45}$ (cognitive-behavioral psychotherapy or only behavioral psychotherapy) are offered only at professional training centers or university hospitals/services. Attempts to extend the reach of these techniques involve group sessions focusing on the writing of treatment manuals ${ }^{45}$ and distance treatment programs (via telephone or internet). ${ }^{46}$ The efficacy of distance programs still has to be demonstrated, whereas group sessions have reported good response rates ${ }^{45}$. However, there are no data available on group cognitivebehavioral therapy offered to resistant or refractory $O C D$ patients.

\section{Other psychosocial barriers}

According to our review, most patients with OCD were not in contact with a mental health professional, and apparently very few were receiving appropriate treatment, namely, SSRIs and cognitive-behavioral therapy. On an internet survey, the majority of patients who sought psychotherapeutic treatment received "talk 
therapy." ${ }^{47}$ In another study, only $5 \%$ of OCD patients were receiving cognitive-behavioral therapy, $2 \%$ were taking SSRIs, and $10 \%$ were taking tricyclic antidepressants. ${ }^{48}$ Logistic difficulties, lack of insurance coverage, shame, and disbelief in treatment effectiveness were the barriers to treatment most most commonly endorsed. ${ }^{47}$

\section{Pharmacological approaches to refractory OCD}

The alternative therapies available to patients not responding to conventional treatment include higher doses of standard therapy, intravenous monotherapy, drug combination/augmentation, and other biological interventions, e.g., the use of fatty acids.

\section{Higher doses of standard therapy}

This strategy appears in some algorithms for the treatment of refractory OCD, however it should be considered with caution, carefully balancing the risks and benefits involved. ${ }^{36}$ Success with doses greater than those recommended in the summary of product characteristics has been shown in some treatment-refractory patients, e.g., sertraline at 250 to $400 \mathrm{mg}$ daily. ${ }^{49}$ Obsessive but not compulsive symptoms also responded faster to high-dose sertraline (200 mg daily). Finally, higher doses of SSRIs were well tolerated and produced similar rates of adverse effects when compared with standard doses, although the severity of such adverse effects may have been higher. Pampaloni et al. described that refractory patients on high-dose treatment showed significant intragroup improvements, although the Y-BOCS scores of the highdose group remained significantly higher than those of control patients treated for the same period. No differences were found between cases and controls regarding adverse effects, although sample size was small and the findings limited by the retrospective study design. ${ }^{50}$

\section{Intravenous monotherapy: clomipramine and citalopram}

There is limited evidence ${ }^{51}$ suggesting benefits of the use of intravenous clomipramine in reducing OCD symptoms as assessed by Y-BOCS. ${ }^{52}$ Some anecdotal cases suggest that pulse intravenous clomipramine may produce a decrease of obsessive-compulsive symptoms in patients who did not respond to or did not tolerate clomipramine taken orally. ${ }^{53}$ However, use of this therapy is limited because of the close medical supervision and cardiac monitoring required during administration. ${ }^{54}$ Citalopram has also demonstrated efficacy in open trials in patients resistant to conventional treatment. ${ }^{55}$ Nevertheless, such intravenous alternatives are not available in most countries.

\section{Serotonin-norepinephrine reuptake inhibitors (SNRI)}

Several case reports have suggested that venlafaxine and duloxetine may be beneficial when used as antiobsessive agents. However, there are no randomized clinical trials (RCTs) confirming this finding. ${ }^{56-59}$

\section{Psilocybin}

Psilocybin is the main psychoactive component found in mushrooms of the genus Psilocybe, more commonly known as "magic mushrooms." Psilocybin acts as an agonist of 5-HT1A, 5-HT2A and 5-HT2C. Moreno et al. conducted a small proof-of-concept study (Phase I) with nine refractory OCD patients who showed improvement of symptoms. ${ }^{60}$ Unfortunately, this study has not been replicated.

\section{Combining drugs to enhance the efficacy of SSRIs}

Due to the multifactorial, heterogeneous etiology of $O C D$, a common strategy has been to combine other drugs with SSRIs so as to activate other neurotransmitters (such as glutamate and dopamine). The combined use of two SSRIs has also been reported. ${ }^{36}$

The drugs most frequently combined with SSRIs are described below.

\section{Trazodone}

Trazodone is an atypical antidepressant with potent antagonist action on $5-\mathrm{HT} 2 / 1 \mathrm{C}$ receptors. Some case reports have described a significant and rapid improvement in symptoms after the introduction of trazodone associated with an SSRI. However, two clinical trials failed to confirm this finding. ${ }^{61,62}$ Despite the growing positive evidence in the literature, adequate RCTs are still needed to better define the role of trazodone in the treatment of OCD. ${ }^{52}$

\section{SNRIs}

The association between citalopram and reboxetine produced a favorable response in one case report. ${ }^{59}$ However, no RCT has so far tested this combination.

\section{Antipsychotics}

A recent meta-analysis conducted by Bloch et al. ${ }^{63}$ concluded that adjuvant treatment with antipsychotics may be useful in cases of refractory OCD patients. The benefits were most evident with the use of risperidone. ${ }^{64-66}$ Haloperidol and pimozide were effective adjuvants in patients with comorbidities such as tics or trichotillomania, ${ }^{67}$ and open-label trials have described a relative effectiveness of olanzapine in combination to SSRIs63-68. This result was confirmed in two RCTs, ${ }^{68}$ suggesting a promising role of these drugs in patients 
refractory to monotherapy with SSRIs. ${ }^{65}$ Other studies, however, have shown conflicting results on the real benefit of olanzapine. ${ }^{66}$

Placebo-controlled RCTs have also shown significant improvement in Y-BOCS scores in refractory patients receiving quetiapine. ${ }^{69,70}$ In the largest of these trials ( $n=66$ ), quetiapine proved to be significantly superior to placebo, but was associated with a higher rate of treatment discontinuation due to adverse effects. A meta-analysis has also suggested that quetiapine may be effective in combination with SSRIs. ${ }^{71}$ However, two open clinical trials showed no efficacy of quetiapine as an adjunctive therapy, and a double-blind, placebocontrolled study showed that quetiapine as an adjunctive therapy was not more effective than placebo. ${ }^{72}$ Finally, one study showed reduction in Y-BOCS scores and improvement of obsessive-compulsive symptoms with the combined use of amisulpride and an SSRI.67

Ziprasidone is an atypical antipsychotic and a potent 5-HT1A receptor agonist, inhibiting the reuptake of serotonin and norepinephrine, which could make this drug more effective than other antipsychotics as an adjuvant treatment in refractory OCD. However, the only comparative study so far conducted has suggested it to be less effective than quetiapine in this population. ${ }^{73}$

\section{Benzodiazepines}

One study compared the use of clonazepam versus placebo in patients treated with clomipramine or fluoxetine and suggested no benefits of this association. ${ }^{72}$ Otherwise, many reports suggest the efficacy of this benzodiazepine when used both alone and as an adjuvant. Negative results have also been reported. ${ }^{65}$ There are case reports showing benefits with alprazolam augmentation, but the existing data are not enough to recommend the regular use of this drug in the treatment of refractory OCD. ${ }^{74}$

Opioids

A randomized double-blind study administered oral morphine (once weekly) and lorazepam to 23 patients with refractory OCD, 17 of whom were receiving other medications at the time of the study (SSRIs, benzodiazepines, antipsychotics, gabapentin, clomipramine, bupropion, topiramate, and trazodone). The result was a rapid but transient improvement of symptoms in some patients, confirming previous findings of case reports and open studies that suggested a role of mu receptors in the treatment of refractory OCD. ${ }^{75}$

Glutamate-modulating drugs

Memantine is an uncompetitive antagonist of $\mathrm{N}$-methyl-D-aspartate (NMDA) receptors that has yielded conflicting results in refractory OCD. ${ }^{76,77}$ Riluzole is an anti-glutamatergic drug used for neuroprotection in patients with amyotrophic lateral sclerosis. An open study used this drug as an adjuvant to SSRI in 13 OCD patients for 8 weeks. Seven (59\%) of the 13 patients showed a $\geq 35 \%$ reduction in Y-BOCS scores, and five (39\%) were considered responders. Despite the small sample size and absence of a control group, this preliminary study is the first to suggest the involvement of glutamatergic dysfunction in the pathophysiology of OCD. ${ }^{78}$

Other drugs

The drugs listed below have shown no evidence of efficacy in treating refractory OCD, but have been used in isolated case reports. Although these drugs may be considered as options in particular cases, extreme caution is recommended in their use.

- Carbamazepine, oxcarbazepine, divalproate, lamotrigine, topiramate: a double-blind study has suggested that topiramate may be useful for compulsions, but not for obsessions, when associated with an SSRI. ${ }^{79}$

- Inositol, 80 pindolol: these drugs seem to benefit partial responders, ${ }^{65}$ but more studies are required to test their use.

- Lithium: the only RCT so far conducted failed to show significant results when compared with placebo as an augmenting agent. ${ }^{65}$

- Thyroid hormone, clonidine, ondansetron (an antiemetic that blocks 5-HT4 and 5-HT3 receptors): when prescribed in combination with SSRIs, these drugs showed positive effects on obsessivecompulsive symptoms after 2 weeks of treatment. ${ }^{81}$

\section{Psychotherapeutic approaches to refractory OCD}

There are limited reports on the use of cognitivebehavioral techniques, such as exposure and response prevention and cognitive therapy, in patients with severe or refractory $O C D$, especially because of the increased anxiety associated with exposure during treatment sessions. ${ }^{47}$ In fact, about $30 \%$ of the patients refuse this type of therapy. ${ }^{82}$ In addition, many patients do not adhere to the exercises or abandon treatment, especially those with pure or overvalued obsessions. ${ }^{83}$ Another limitation of these techniques is that some patients may resist performing rituals during the session, but will either compensate for them later, at home, or perform them mentally, not to be noted by the therapist. ${ }^{47}$

Some authors have suggested cognitive techniques as an alternative treatment for patients resistant to exposure and response prevention. The following 
strategies are frequently used : discussion of automatic and intrusive thoughts, fear, and dysfunctional schemas; modification of unrealistic interpretations ${ }^{84}$; and discussion of magical thinking and thought-action fusion. Explaining the purpose of rituals and Socratic questioning are also important 83,85 and may benefit patients with obsessive thoughts even in the absence of compulsive behavior. ${ }^{84}$ Analysis of patients' beliefs and rules can motivate them for treatment. This method used as the only therapy still lacks confirmatory studies, ${ }^{86}$ and the evidence suggesting that dysfunctional beliefs of OCD sufferers are different from those present in other disorders is still inconclusive. ${ }^{82}$

Alternative psychotherapeutic treatments have been studied in patients refractory to conventional cognitivebehavioral therapy. Family-based therapies, for example, have been studied in children, with good results. ${ }^{87}$

Some authors have advocated the advantages of involving both patients and family groups in therapy sessions. One study evaluated a cognitive-behavioral therapy group comprised of family members and patients who had started conventional individual treatment. The families discussed the impact of symptoms on family planning and coping strategies, while the patients performed behavioral tasks in the group. ${ }^{88}$

Recently, studies have emphasized the importance of psychoeducational techniques for family support groups. Sessions should provide information regarding diagnosis, evaluation, OCD theories, behavioral techniques, medications, and relapse prevention. ${ }^{38}$

Thornicroft et al. ${ }^{89}$ described the results obtained in a group of patients treated with behavioral therapy, exposure and response prevention, self-control strategies, and social skills training. The family component was to reduce parental involvement in rituals, training them to monitor patients and encourage them to expose themselves, however without criticizing them. Family approaches have been shown to be superior to conventional treatments not using this approach. Strategies should include information on biological, psychological, and social strategies for dealing with OCD behaviors $^{38}$ in order to reduce family accommodation and improve expressed emotions. ${ }^{90}$

Other approaches for refractory patients include inhospital treatment ${ }^{91}$ and intensive cognitive-behavioral therapy. ${ }^{89}$ In-hospital treatment has some limitations because it requires trained nurses, nursing assistants, psychiatrists, and therapists. In addition, the number of specialized hospitals is low. ${ }^{91}$ Intensive cognitivebehavioral treatment is conducted for a shorter period, with more frequent and longer-lasting sessions. Studies including adults and children have demonstrated efficacy of this treatment. ${ }^{89}$ Conversely, no clinical effects on obsessive-compulsive and depressive symptoms were observed after brief dynamic therapy in OCD patients with comorbid depression. ${ }^{92}$

D-cycloserine augmentation of habituation and exposure therapy has been tested in patients with $\mathrm{OCD}^{47}$ and proved effective for other anxiety disorders. ${ }^{93}$ The potential effectiveness of D-cycloserine is based on the theory that NMDA plays a primary role in neural processes, associations, and in the extinction of learned fear - all principles of exposure therapy. ${ }^{94,95}$ Habituation is the spontaneous disappearance of fear or discomfort reactions as the individual repeatedly comes into contact with objects or situations that provoke such reactions but are not actually dangerous. ${ }^{82}$ The use of D-cycloserine would facilitate this learning process and thus improve therapeutic response. ${ }^{47}$ The efficacy of this agent in patients with resistant or refractory OCD has been little studied. Two studies have suggested a faster response to behavioral therapy with exposure and response prevention in patients receiving $D$-cycloserine when compared to a placebo group. ${ }^{96,97}$ Other studies, however, found no differences between these groups in either adults ${ }^{93}$ or children. ${ }^{95}$

\section{Neurobiological approaches}

The principle underlying the use of neurobiological procedures in OCD is the selective division of brain areas that interconnect the hyperactive cortical-striatalthalamic-cortical circuit. Among several neuroanatomical methods currently available, repetitive transcranial magnetic stimulation (rTMS), transcranial direct current stimulation (TDCS), vagus nerve stimulation (VNS), and deep brain stimulation (DBS) deserve special mention, in addition to the well-known neurosurgical techniques. ${ }^{98,99}$

\section{Electroconvulsive therapy (ECT)}

There are only case reports describing the use of ECT in OCD patients. A recent review of 32 cases of refractory OCD patients reported that most subjects showed considerable improvement in obsessive-compulsive symptoms and remained improved up to 1 year after therapy. Treatment response remained significant even after controlling for depressive symptoms, pointing to the need for further investigation regarding the use of ECT in OCD. 100

\section{Repetitive transcranial magnetic stimulation (rTMS)}

Since 1997, a total of 110 OCD patients have been treated with rTMS in published trials. ${ }^{101}$ Greenberg et al. ${ }^{102}$ found that a single session of high-frequency rTMS to the right lateral prefrontal cortex significantly decreased 
compulsive urges. Conversely, a double-blind study using right prefrontal low-frequency rTMS failed to find significant effects. ${ }^{103}$ An open study involving refractory OCD patients assigned to right or left dorsolateral prefrontal cortex stimulation with high-frequency rTMS found clinically significant and sustained improvement in a third of the patients. ${ }^{104}$ In another recent study, neither low- nor high-frequency rTMS to the left dorsolateral prefrontal cortex produced significant effects when compared with placebo. ${ }^{104,105}$

A recent neuroimaging study suggested that premotor areas such as the supplementary motor area are hyperactive in $O C D$, and that this hyperactivity may result in deficient inhibitory control. ${ }^{106}$ The most recent randomized sham-controlled double-blind study of rTMS in OCD assigned 21 medication-resistant OCD patients to 4 weeks of active or sham rTMS bilaterally to the supplementary motor area. ${ }^{107}$ The response rate among completers was $67 \%$ (6/9) for active and $22 \%$ (2/9) for sham rTMS. At 4 weeks, patients receiving active rTMS showed on average a $25 \%$ reduction in Y-BOCS scores, compared with a $12 \%$ reduction in those receiving sham. These results support further investigation into the potential therapeutic applications of rTMS in this disabling condition.

\section{Deep brain stimulation (DBS)}

The first experiment describing the use of DBS in OCD was carried out in Stockholm in 1998 at the Karolinska Hospital. Based on published trials and case studies, it is estimated that more than 100 individuals have received experimental DBS treatment for OCD. ${ }^{108}$ DBS is a neurosurgical treatment involving the implantation of electrodes that send electrical impulses to specific brain locations, selected according to the type of symptoms to be addressed. ${ }^{108}$

Several techniques and brain targets are described in the literature for DBS. The choice of the anterior limb of internal capsule (ALIC) as a brain target was based on previous experience with anterior capsulotomy for refractory OCD. This neurosurgical procedure had shown positive results in approximately $50 \%$ of participants. ${ }^{109,110}$

Some structures adjacent to the internal capsule have also been targeted for DBS, including the ventral striatum, comprised of a ventral caudate nucleus and a nucleus accumbens and thought to be associated with reward and motivation mechanisms. Combined with the ventral capsule, this area is referred to as the ventral capsule/ventral striatum region. This brain target was chosen based on positive results previously obtained following gamma knife capsulotomy at the ventral region of the ALIC for refractory OCD. ${ }^{111}$ The subthalamic nucleus and the inferior thalamic peduncle have also been described as possible targets. ${ }^{108}$

Notwithstanding, the mechanism of action of DBS in OCD remains unclear. Functional imaging studies of DBS applied to ALIC $^{112}$ and the subthalamic nucleus ${ }^{113}$ have shown normal activity of the orbitofrontal cortex (OFC), suggesting a final common cortical-striatal pathway. Conversely, current data suggest no decline or improvement of cognitive function caused by DBS ${ }^{108}$. Serious procedure-related events are rare, and side effects can be reversed by cessation or adjustment of stimulation parameters. In sum, DBS is a promising and apparently safe therapy for patients with treatmentrefractory $O C D$, but further investigation is still needed.

\section{Neurosurgical treatments}

The rates of global improvement after different neurosurgical techniques are quite variable: capsulotomy, 56 to $100 \%$; cingulotomy, 27 to $57 \%$; subcaudate tractotomy, 33 to $67 \%$; limbic leucotomy, 61 to $69 \%$; and thalamotomy/pallidotomy, $62.5 \%{ }^{36}$ Radiosurgery has the advantages of not requiring cranial opening and having a zero risk of hemorrhage and infection, with efficacy rates ranging from 37.5 and $70 \% .{ }^{110,111}$

The adverse events and complications associated with neurosurgical treatments of OCD vary according to surgical technique (lesion site). The most prevalent adverse effects are isolated cases of seizures, delirium immediately after surgery, hypomania, and, rarely, hemorrhage and neuroinfection. ${ }^{111}$ In radiosurgery, the most frequent side effects are headache episodes. Neuropsychological alterations are rare; when present, they usually manifest as apathy, mental slowness, irritability, aggressiveness, and lack of behavioral inhibition. These complications, however, are more common with the old techniques (especially limbic leucotomy and subcaudate tractotomy). ${ }^{111}$

\section{Vagus nerve stimulation (VNS)}

Vagus nerve stimulation (VNS) is an effective anticonvulsant technique and has shown antidepressant effects in chronic treatment-resistant depression. ${ }^{114}$ Out of seven adult outpatients with treatment-resistant OCD who received stimulation, three (43\%) were acute responders based on Y-BOCS scores, and there was some improvement in Y-BOCS scores over time. ${ }^{114}$ Further studies are warranted to assess the role of VNS in refractory $O C D$.

\section{Conclusion}

There have been significant advances in the pharmacotherapy of OCD over the last decades, but 
further work remains to be done. Extensive evidence exists to support the efficacy of clomipramine and SSRIs in the treatment of OCD. Antipsychotic augmentation is recommended, but is effective and well tolerated only in some patients. Cognitive-behavioral therapy is another key development, but access to well-trained practitioners remains a problem in many countries. Finally, there have been significant advances in uncovering the neurobiology of OCD, and ongoing work may ultimately translate into novel approaches, e.g., deep brain stimulation or magnetic transcranial stimulation for the treatment of OCD. This review suggest that clinicians dealing with refractory $O C D$ patients should: 1) review intrinsic phenomenological aspects of OCD, which could lead to different interpretations and thus to the selection of different therapeutic approaches; 2) review extrinsic phenomenological aspects of $O C D$, especially family accommodation, which may be a risk factor for non-response; 3) consider non-conventional pharmacological approaches; 4) consider nonconventional psychotherapeutic approaches; and 5) consider neurobiological approaches.

\section{References}

1. Ruscio AM, Stein DJ, Chiu WT, Kessler RC. The epidemiology of obsessive-compulsive disorder in the National Comorbidity Survey Replication. Mol Psychiatry. 2010;15:53-63.

2. Fontenelle LF, Mendlowicz MV, Versiani M. The descriptive epidemiology of obsessive-compulsive disorder. Prog Neuropsychopharmacol Biol Psychiatry. 2006;30:327-37.

3. Frank E, Prien RF, Jarrett RB, Keller MB, Kupfer DJ, Lavori PW, et al. Conceptualization and rationale for consensus definitions of terms in major depressive disorder. Remission, recovery, relapse, and recurrence. Arch Gen Psychiatry. 1991;48:851-5.

4. Ferrão YA, Fontenelle LF. Discussing resistant and refractory cases in psychiatry. Rev Bras Psiquiatr. 2007;29 Suppl 2:S39-40.

5. de Haan $E$, van Oppen $P$, van Balkom AJ, Spinhoven $P$, Hoogduin KA, Van Dyck R. Prediction of outcome and early vs. late improvement in OCD patients treated with cognitive behaviour therapy and pharmacotherapy. Acta Psychiatr Scand. 1997; 96:354-61.

6. Rasmussen SA, Eisen JL. Treatment strategies for chronic and refractory obsessive-compulsive disorder. J Clin Psychiatry. 1997;58 Suppl 13:9-13.

7. Goodman WK, Price LH. Assessment of severity and change in obsessive compulsive disorder. Psychiatr Clin North Am. 1992;15:861-9.

8. Goodman WK, Price LH, Delgado PL, Palumbo J, Krystal JH, Nagy LM, et al. Specificity of serotonin reuptake inhibitors in the treatment of obsessive-compulsive disorder. Comparison of fluvoxamine and desipramine. Arch Gen Psychiatry. 1990;47:577-85.

9. Simpson HB, Huppert JD, Petkova E, Foa EB, Liebowitz MR. Response versus remission in obsessive-compulsive disorder. J Clin Psychiatry. 2006;67:269-76.
10. Mavissakalian M, Turner SM, Michelson L, Jacob R. Tricyclic antidepressants in obsessive-compulsive disorder: antiobsessional or antidepressant agents? II. Am J Psychiatry. 1985;142:572-6.

11. Tolin DF, Abramowitz JS, Diefenbach GJ. Defining response in clinical trials for obsessive-compulsive disorder: a signal detection analysis of the Yale-Brown Obsessive Compulsive Scale. J Clin Psychiatry. 2005;66:1549-57.

12. Pallanti S, Hollander E, Bienstock C, Koran L, Leckman J, Marazziti D, et al. Treatment non-response in OCD: methodological issues and operational definitions. Int ] Neuropsychopharmacol. 2002;5:181-91.

13. Jenike MA, Rauch SL. Managing the patient with treatmentresistant obsessive compulsive disorder: current strategies. J Clin Psychiatry. 1994;55 Suppl:11-7.

14. Hounie AG, Brotto SA, Diniz J, Chacon PJ, Miguel EC. Transtorno obsessivo-compulsivo: possíveis subtipos. Rev Bras Psiquiatr. 2001;23(Supl II):13-6.

15. Robins LN, Helzer JE, Weissman MM, Orvaschel H, Gruenberg E, Burke JD-Jr. Lifetime prevalence of specific psychiatric disorders in three sites. Arch Gen Psychiatry. 1984;41:959-67.

16. Boschen MJ, Drummond LM, Pillay A, Morton K. Predicting outcome of treatment for severe, treatment resistant OCD in inpatient and community settings. J Behav Ther Exp Psychiatry. 2010;41:90-5.

17. Ferrão YA, Shavitt RG, Bedin NR, de Mathis ME, Carlos Lopes A, Fontenelle LF, et al. Clinical features of refractory obsessive compulsive patients. J Affective Disord. 2006;94:199-209.

18. Matsunaga $H$, Hayashida $K$, Kiriike N, Nagata T, Stein DJ. Clinical features and treatment characteristics of compulsive hoarding in Japanese patients with obsessive-compulsive disorder. CNS Spectr. 2010;15:231-6.

19. Philips KA, McElroy SL. Insight, overvalued ideas and delusional thinking in body dysmorphic disorder: theoretical and treatment implications. J Nerv Ment Dis. 1993;181:699-702.

20. Neziroglu FA, Yaryura-Tobias JA. Exposure, response prevention, and cognitive therapy in the treatment of body dysmorphic disorder. Behav Ther. 1993;24:431-8.

21. Foa EB. Failures in treating obsessive-compulsives. Behav Res Ther. 1979;17:169-76.

22. Abel JL. Exposure and response prevention and serotonergic antidepressants in the treatment of obsessive-compulsive disorder: a review and implications for interdisciplinary treatment. Behav Res Ther. 1993;31:463-78.

23. Neziroglu FA, Stevens KP, Yaryura Tobias JA. Overvalued ideas and their impact on treatment outcome. Rev Bras Psiquiatr. 1999;21:209-16.

24. Pace SM, Thwaites R, Freeston MH. Exploring the role of external criticism in obsessive compulsive disorder: a narrative review. Clin Psychol Rev. 2011;31:361-70.

25. Chambless DL, Blake KD, Simmons RA. Attributions for relatives' behavior and perceived criticism: studies with community participants and patients with anxiety disorders. Behav Ther. 2010;41:388-400.

26. Eisen JL, Phillips KA, Baer L, Beer DA, Atala KD, Rasmussen AS. The Brown Assessment of Beliefs Scale (BABS): reliability and validity. Am J Psychiatry. 1998;155:102-8.

27. Corchs F, Corregiari F, Ferrão YA, Takakura T, Mathis ME, Lopes AC, et al. Personality traits and treatment outcome in obsessive-compulsive disorder. Rev Bras Psiquiatr. 2008; 30:246-50.

28. Baer $L$, Jenike MA. Personality disorders in obsessive compulsive disorder. Psychiatr Clin North Am. 1992;15:803-12. 
29. Moritz S, Fricke S, Jacobsen D, Kloss M, Wein C, Rufer M, et al. Positive schizotypal symptoms predict treatment outcome in obsessive-compulsive disorder. Behav Res Ther. 2004; $42: 217-27$.

30. McDougle CJ, Goodman WK, Leckman JF, Lee NC, Heninger $\mathrm{GR}$, Price LH. Haloperidol addition in fluvoxamine-refractory obsessive-compulsive disorder: a double blind, placebo controlled study in patients with and without tics. Arch Gen Psychiatry. 1994;51:302-8.

31. Ackerman DL, Greenland S, Bystrystky A, Morgenstern H, Katz RJ. Predictors of treatment response in obsessivecompulsive disorder: multivariate analyses from a multicenter trial of clomipramine. J Clin Psychopharmacol. 1994; 14:247-54.

32. Fontenelle L, Marques C, Versiani M. The effect of gender on the clinical features and therapeutic response in obsessivecompulsive disorder. Rev Bras Psiquiatr. 2002;24:7-11.

33. Ackerman DL, Greenland S, Bystritsky A. Side effects as predictors of drug response in obsessive-compulsive disorder. J Clin Psychopharmacol. 1999;19:459-65.

34. Alarcon RD, Libb JW, Spitler D. A predictive study of obsessive compulsive disorder response to clomipramine. J Clin Psychopharmacol. 1993;13:210-3.

35. Ravizza L, Barzega G, Bellino S, Bogetto F, Maina G. Predictors of drug treatment response in obsessivecompulsive disorder. J Clin Psychiatry. 1995;56:368-73.

36. Ferrão YA, Diniz JB, Lopes AC, Shavitt RG, Greenberg B, Miguel E. Resistance and refractoriness in obsessivecompulsive disorder. Rev Bras Psiquiatr. 2007;29 Suppl 2:S66-76.

37. Calvocoressi L, Lewis B, Harris M, Trufan S, Goodman WK, McDougle $C J$, et al. Family accommodation in obsessivecompulsive disorder. Am J Psychiatry. 1995;152:441-3.

38. Calvocoressi L, Mazure C, Kasl S, Skolnick J, Fisk D, Vegso $\mathrm{SJ}$, et al. Family accommodation of obsessive-compulsive symptoms: instrument development and assessment of family behavior. J Nerv Mental Dis. 1999;187:636-642.

39. Steketee G, Van Noppen B. Family approaches to treatment for obsessive compulsive disorder. Rev Bras Psiquiatr. 2003; $25: 43-50$.

40. Steketee G, Lam JN, Chambless DL, Rodebaugh TL, McCullouch CE. Effects of perceived criticism on anxiety and depression during behavioral treatment. Behav Res Ther. 2007; $45: 11-9$

41. Chambless DL, Steketee G. Expressed emotion and behavior therapy outcome: A prospective study with obsessive-compulsive and agoraphobic patients. J Consult Clin Psychol. 1999;67:658-65.

42. Emmelkamp PM, Hoekstra RJ, Visser A. The behavioral treatment of obsessive-compulsive disorder: prediction of outcome at 3,5 years follow-up. In: Pichot P, Berner $P$, Wolf R, Thau K. Psychiatry: the state of the art. New York: Plenum; 1985. p. 265-70.

43. Greenberg BD, Pinto A, Mancebo M, Eisen J, Rasmussen SA. Obsessive-compulsive disorder: recognition across medical settings, and treatments from behavior therapy to neurosurgery. Med Health R I. 2006;89:162-5.

44. Koran L. Quality of life in obsessive-compulsive disorder. Psychiatr Clin North Am. 2000;23:509-17.

45. Volpato Cordioli A, Heldt E, Braga Bochi D, Margis R, Basso de Sousa M, Fonseca Tonello J, et al. Cognitive-behavioral group therapy in obsessive-compulsive disorder: a randomized clinical trial. Psychother Psychosom. 2003;72:211-6.
46. Baer L, Minichiello WE. Internet assessment of obsessive compulsive disorder. J Clin Psychiatry. 2006;67:1473.

47. Marques L, LeBlanc NJ, Weingarden HM, Timpano KR, Jenike $M$, Wilhelm S. Barriers to treatment and service utilization in an internet sample of individuals with obsessive-compulsive symptoms. Depress Anxiety. 2010;27:470-5.

48. Torres AR, Prince MJ, Bebbington PE, Bhugra DK, Brugha TS, Farrell $M$, et al. Treatment seeking by individuals with obsessive-compulsive disorder from the British Psychiatric Morbidity Survey of 2000 psychiatric services. Psychiatr Serv. 2007;58:977-82.

49. Ninan PT, Koran LM, Kiev A, Davidson JR, Rasmussen SA, Zajecka JM, et al. High-dose sertraline strategy for nonresponders to acute treatment for obsessive-compulsive disorder: a multicenter double-blind trial. J Clin Psychiatry. 2006;67:15-22.

50. Pampaloni I, Sivakumaran T, Hawley CJ, Al Allaq A, Farrow J, Nelson S, et al. High-dose selective serotonin reuptake inhibitors in OCD: a systematic retrospective case notes survey. J Psychopharmacol. 2010;24:1439-45.

51. Koran LM, Sallee FR, Pallanti S. Rapid benefit of intravenous pulse loading of clomipramine in obsessive-compulsive disorder. Am J Psychiatry. 1997;154:396-401.

52. The British Psychological Society, The Royal College of Psychiatrists. Obsessive-compulsive disorder: core interventions in the treatment of obsessive-compulsive disorder and body dysmorphic disorder. National Collaborating Centre for Mental Health. London: British Psychological Society, Royal College of Psychiatrists; 2006.

53. Kochan LD, Qureshi AI, Fallon BA. Therapeutic approaches to the treatment of refractory obsessive-compulsive disorder. Curr Psychiatry Rep. 2000;2:327-34.

54. Ravindran LN, Stein MB. The pharmacologic treatment of anxiety disorders: a review of progress. J Clin Psychiatry. 2010;71:839-54.

55. Pallanti S, Quercioli L, Koran LM. Citalopram intravenous infusion in resistant obsessive-compulsive disorder: an open trial. J Clin Psychiatry. 2002;63:796-801.

56. Dell'Osso B, Nestadt G, Allen A, Hollander E. Serotoninnorepinephrine reuptake inhibitors in the treatment of obsessive-compulsive disorder: a critical review. J Clin Psychiatry. 2006;67:600-10

57. Dell'osso B, Mundo E, Marazziti D, Altamura AC. Switching from serotonin reuptake inhibitors to duloxetine in patients with resistant obsessive compulsive disorder: a case series. J Psychopharmacol. 2008;22:210-3.

58. Phelps NJ, Cates ME. The role of venlafaxine in the treatment of obsessive compulsive disorder. Ann Pharmacother. 2005;39:136-40.

59. Fontenelle LF, Mendlowicz MV, Miguel EC, Versiani M. Citalopram plus reboxetine in treatment-resistant obsessivecompulsive disorder. World J Biol Psychiatry. 2005;6:57-9.

60. Moreno FA, Wiegand CB, Taitano EK, Delgado PL. Safety, efficacy and tolerability of psilocybin in 9 patients with obsessive-compulsive disorder. J Clin Psychiatry. 2006;67:1735-40.

61. Rocha FF, Corrêa H, Lage NV. Addition of trazodone to sertraline: a probable synergistic action in a case of obsessive-compulsive disorder. Rev Bras Psiquiatr. 2007;29:381-2.

62. Pigott TA, L'Heureux F, Rubenstein CS, Bernstein SE, Hill $\mathrm{JL}$, Murphy DL. A double-blind, placebo controlled study of trazodone in patients with obsessive-compulsive disorder. J Clin Psychopharmacol. 1992;12:156-62. 
63. Bloch MH, Landeros-Weisenberger A, Kelmendi B, Coric V, Bracken MB, Leckman JF. A systematic review: antipsychotic augmentation with treatment refractory obsessivecompulsive disorder. Mol Psychiatry. 2006;11:622-32.

64. Schruers K, Koning K, Luermans J, Haack MJ, Griez E. Obsessive-compulsive disorder: a critical review of therapeutic perspectives. Acta Psychiatr Scand. 2005;111:261-71.

65. Hollander E, Bienstock CA, Koran LM, Pallanti S, Marazziti $D$, Rasmussen SA, et al. Refractory obsessive-compulsive disorder: state-of-art treatment. J Clin Psychiatry. 2002; 63(6 suppl):20-9.

66. Decloedt E, Stein DJ. Current trends in drug treatment of obsessive-compulsive disorder. Neuropsychiatr Dis Treat. 2010;6:233-42.

67. Gao K, Muzina D, Gajwani P, Calabrese JR. Typical and atypical antipsichotics for primary and comorbid anxiety disorders or symptoms: a review. J Clin Psychiatry. 2006;67:1327-40.

68. Komossa K, Depping AM, Meyer M, Kissling W, Leucht S. Second-generation antipsychotics for obsessive compulsive disorder. Cochrane Database Syst Rev. 2010;12:CD008141.

69. Diniz JB, Shavitt RG, Pereira CA, Hounie AG, Pimentel I, Koran LM, et al. Quetiapine versus clomipramine in the augmentation of selective serotonin reuptake inhibitors for the treatment of obsessive-compulsive disorder: a randomized, open-label trial. J Psychopharmacol. 2010;24:297-307.

70. Diniz JB, Shavitt RG, Fossaluza V, Koran L, Pereira CA, Miguel EC. A double-blind, randomized, controlled trial of fluoxetine plus quetiapine or clomipramine versus fluoxetine plus placebo for obsessive-compulsive disorder. J Clin Psychopharmacol. 2011;31:763-8.

71. Vulink NC, Denys D, Fluitman SB, Meinardi JC, Westenberg HG. Quetiapine augments the effect of citalopram in nonrefractory obsessive-compulsive disorder: a randomized, double-blind, placebo-controlled study of 76 patients. J Clin Psychiatry. 2009;70:1001-8.

72. Choi Y-J. Efficacy of treatment for patients with obsessive compulsive disorder - a systematic review. J Am Acad Nurse Pract. 2009;21:207-13.

73. Savas HA, Yumru M, Ozen ME. Quetiapine and ziprasidone as adjuncts in treatment-resistant obsessive-compulsive disorder: a retrospective comparative study. Clin Drug Investig. 2008;28:439-42.

74. Math SB, Reddy J. Pharmacological issues in the treatment of obsessive compulsive disorder. Int $\mathrm{J}$ Clin Pract. 2007;61:1170-80.

75. Koran LM, Aboujaoude E, Bullock KD, Franz B, Gamel N, Elliott M. Double-blind treatment with oral morphine in treatment-resistant obsessive-compulsive disorder. J Clin Psychiatry. 2005;66:353-9.

76. Aboujaoude E, Barry JJ, Gamel N. Memantine augmentation in treatment-resistant obsessive-compulsive disorder: an open-label trial. J Clin Psychopharmacol. 2009;29:51-5.

77. Zdanys K, Tampi RR. A systematic review of off-label uses of memantine for psychiatric disorders. Prog Neuropsychopharmacol Biol Psychiatry. 2008;32:1362-74.

78. Mahgoub N, Asemota B, Alexopoulos GS. The effect of riluzole augmentation in a patient with treatment-resistant obsessivecompulsive disorder, taking two other glutaminergic agents. J Neuropsychiatry Clin Neurosci. 2011;23:E24-5.

79. Berlin HA, Koran LM, Jenike MA, Shapira NA, Chaplin W, Pallanti $S$, et al. Double-blind, placebo-controlled trial of topiramate augmentation in treatment-resistant obsessivecompulsive disorder. J Clin Psychiatry. 2011;72:716-21.
80. Harvey BH, Scheepers A, Brand L, Stein DJ. Chronic inositol increases striatal $\mathrm{D}(2)$ receptors but does not modify dexamphetamine-induced motor behavior. Relevance to obsessive-compulsive disorder. Pharmacol Biochem Behav. 2001;68:245-53.

81. Soltani F, Sayyah M, Feizy F, Malayeri A, Siahpoosh A, Motlagh I. A double-blind, placebo-controlled pilot study of ondansetron for patients with obsessive-compulsive disorder. Hum Psychopharmacol. 2010;25:509-13.

82. Cordioli AV. Cognitive-behavioral therapy in obsessivecompulsive disorder. Rev Bras Psiquiatr. 2008;30 Suppl 2:s65-72.

83. Prazeres AM, Souza WF, Fontenelle LF. Cognitive-behavior therapy for obsessive-compulsive disorder: a systematic review of the last decade. Rev Bras Psiquiatr. 2007;29:262-70.

84. Polman A, Bouman TK, van Hout WJ, de Jong PJ, den Boer JA. Processes of change in cognitive-behavioural treatment of obsessive-compulsive disorder: current status and some future directions. Clin Psychol Psychother. 2010;17:1-12.

85. Storch EA, Mariaskin A, Murphy TK. Psychotherapy for obsessive-compulsive disorder. Curr Psychiatry Rep. 2009;11:296-301.

86. Lotufo Neto F, Baltieri MA. Processos cognitivos e seu tratamento no transtorno obsessivo compulsivo. Rev Bras Psiquiatr. 2001;23(Supl II):46-8.

87. Mancuso E, Faro A, Joshi G, Geller DA. Treatment of pediatric obsessive-compulsive disorder: a review. J Child Adolesc Psychopharmacol. 2010;20:299-308.

88. Marks IM, Hodgson R, Rachman S. Treatment of chronic obsessive-compulsive neurosis by in-vivo exposure. A twoyear follow-up and issues in treatment. $\mathrm{Br} J$ Psychiatry. 1975; $127: 349-64$.

89. Thornicroft G, Colson L, Marks I. An in-patient behavioural psychotherapy unit. Description and audit. $\mathrm{Br}$ J Psychiatry. 1991;158:362-7.

90. Piacentini J, Bergman RL, Jacobs C, McCracken JT, Kretchman J. Open trial of cognitive behavior therapy for childhood obsessive-compulsive disorder. J Anxiety Disord. 2002;16:207-19.

91. Calvocoressi L, McDougle CI, Wasylink S, Goodman WK, Trufan SJ, Price LH. Inpatient treatment of patients with severe obsessive-compulsive disorder. Hosp Community Psychiatry. 1993;44:1150-4.

92. Maina G, Rosso G, Rigardetto S, Chiadò Piat S, Bogetto F. No effect of adding brief dynamic therapy to pharmacotherapy in the treatment of obsessive-compulsive disorder with concurrent major depression. Psychother Psychosom. 2010;79:295-302.

93. Hofmann SG, Meuret AE, Smits JA, Simon NM, Pollack MH, Eisenmenger $\mathrm{K}$, et al. Augmentation of exposure therapy with D-cycloserine for social anxiety disorder. Arch Gen Psychiatry. 2006;63:298-304.

94. Storch EA, Merlo LJ, Bengtson M, Murphy TK, Lewis MH, Yang MC, et al. D-cycloserine does not enhance exposureresponse prevention therapy in obsessive-compulsive disorder. Int Clin Psychopharmacol. 2007;22:230-7.

95. Storch EA, Murphy TK, Goodman WK, Geffken GR, Lewin AB, Henin $A$, et al. A preliminary study of $D$-cycloserine augmentation of cognitive-behavioral therapy in pediatric obsessivecompulsive disorder. Biol Psychiatry. 2010;68:1073-6.

96. Wilhelm S, Buhlmann U, Tolin DF, Meunier SA, Pearlson $\mathrm{GD}$, Reese $\mathrm{HE}$, et al. Augmentation of behavior therapy with D-cycloserine for obsessive-compulsive disorder. Am J Psychiatry. 2008;165:335-41; quiz 409. 
97. Chasson GS, Buhlmann U, Tolin DF, Rao SR, Reese HE, Rowley $\mathrm{T}$, et al. Need for speed: evaluating slopes of OCD recovery in behavior therapy enhanced with $d$-cycloserine. Behav Res Ther. 2010;48:675-9.

98. Lopes AC, de Mathis ME, Canteras MM, Salvajoli JV, Del Porto JA, Miguel EC. Atualização sobre o tratamento neurocirúrgico do transtorno obsessivo-compulsivo. Rev Bras Psiquiatr. 2004;26:62-6.

99. Miguel EC, Lopes AC, Guertzenstein EZ, Calazas ME, Teixeira MJ, Brasil MA. Diretrizes para a neurocirurgia dos transtornos psiquiátricos graves no Brasil: uma proposta preliminar. Rev Bras Psiquiatr. 2004;26:8-9.

100. Maletzky B, McFarland B, Burt A. Refractory obsessive compulsive disorder and ECT. Convuls Ther. 1994;10:34-42.

101. Blom RM, Figee M, Vulink N, Denys D. Update on repetitive transcranial magnetic stimulation in obsessivecompulsive disorder: different targets. Curr Psychiatry Rep. 2011;13:289-94.

102. Greenberg BD, George MS, Martin JD, Benjamin J, Schlaepfer TE, Altemus M, et al. Effect of prefrontal repetitive transcranial magnetic stimulation in obsessivecompulsive disorder: a preliminary study. Am J Psychiatry. 1997; 154:867-9.

103. Alonso P, Pujol J, Cardoner N, Benlloch L, Deus J, Menchón JM, et al. Right prefrontal repetitive transcranial magnetic stimulation in obsessive-compulsive disorder: a double-blind, placebo-controlled study. Am J Psychiatry. 2001;158:1143-5.

104. Sachdev PS, McBride R, Loo CK, Mitchell PB, Malhi GS, Croker VM. Right versus left prefrontal transcranial magnetic stimulation for obsessive-compulsive disorder: a preliminary investigation. J Clin Psychiatry. 2001;62:981-4.

105. Prasko J, Pasková B, Zálesky R, Novák T, Kopecek M, Bares $M$, et al. The effect of repetitive transcranial magnetic stimulation (rTMS) on symptoms in obsessive compulsive disorder. A randomized, double blind, sham controlled study. Neuro Endocrinol Lett. 2006;27:327-32.

106. Yücel M, Harrison BJ, Wood SJ, Fornito A, Wellard RM, Pujol $\mathrm{J}$, et al. Functional and biochemical alterations of the medial frontal cortex in obsessive-compulsive disorder. Arch Gen Psychiatry. 2007;64:946-55.
107. Mantovani A, Simpson HB, Fallon BA, Rossi S, Lisanby SH. Randomized sham-controlled trial of repetitive transcranial magnetic stimulation in treatment-resistant obsessivecompulsive disorder. Int J Neuropsychopharmacol. 2010;13:217-27.

108. Koning PP, Figee $M$, van den Munckhof $P$, Schuurman PR, Denys D. Current status of deep brain stimulation for obsessive-compulsive disorder: a clinical review of different targets. Curr Psychiatry Rep. 2011;13:274-82.

109. Lipsman N, Neimat JS, Lozano AM. Deep brain stimulation for treatment refractory obsessive-compulsive disorder: the search for a valid target. Neurosurgery. 2007;61:1-11.

110. Mindus P, Rasmussen SA, Lindquist C. Neurosurgical treatment for refractory obsessive-compulsive disorder: implications for understanding frontal lobe function. J Neuropsychiatry Clin Neurosci. 1994;1:26-36.

111. Lopes AC, Greenberg BD, Norén G, Canteras MM, Busatto GF, de Mathis ME, et al. J Neuropsychiatry Clin Neurosci. 2009;21:381-92.

112. Greenberg BD, Price LH, Rauch SL. Neurosurgery for intractable obsessive-compulsive disorder and depression: critical issues. Neurosurg Clin N Am. 2003;14:199-212.

113. Abelson JL, Curtis GC, Sagher O, Albucher RC, Harrigan M, Taylor SF, et al. Deep brain stimulation for refractory obsessive compulsive disorder. Biol Psychiatry. 2005;57:510-6.

114. George MS, Ward HE, Ninan PT, Pollack M, Nahas Z, Anderson $B$, et al. A pilot study of vagus nerve stimulation (VNS) for treatment-resistant anxiety disorders. Brain Stimul. 2008;1:112-21.

\section{Correspondence}

Ygor Arzeno Ferrão, MD, PhD

Psychiatry Department

Universidade Federal de Ciências da Saúde de Porto Alegre

Rua Padre Chagas, 185/902

90570-080 - Porto Alegre, RS - Brazil

Tel.: +55-51-3346.1077

Fax: +55-51-33461.077

E-mail: ygoraf@ufcspa.edu.br 